\title{
PENGEMBANGAN MODUL IPA MATERI HUBUNGAN MAKHLUK HIDUP DAN LINGKUNGANNYA BERBASIS PENDEKATAN KONTEKSTUAL
}

\author{
Sari Damara Gita ${ }^{1}$, Muhsinah Annisa ${ }^{2}$, A. Wilda Indra Nanna ${ }^{3}$ \\ Universitas Borneo Tarakan ${ }^{1,2,3}$ \\ qiqi.adhe@gmail.com ${ }^{1}$, echa.ok@gmail.com ${ }^{2}$,wiradjab@gmail.com ${ }^{3}$
}

\begin{abstract}
ABSTRAK
Penelitian ini bertujuan untuk menghasilkan bahan ajar berupa Modul IPA materi makhluk hidup dan lingkungannya berbasis pendekatan kontekstual yang berkualitas ditinjau dari dari validasi ahli dan uji coba kepada siswa. Penelitian pengembangan ini menggunakan prosedur pengembangan model ADDIE (analysis, design, development, implementation, evaluation). Subjek penelitian ini adalah siswa kelas IV-B SD Negeri 033 Tarakan dengan jumlah sebanyak 24 orang. Kriteria kualitas modul IPA materi hubungan makhluk hidup dan lingkungannya, dilihat hasil validasi materi 98\% (sangat valid), validasi desain $87.5 \%$ (sangat valid), validasi bahasa 97\% (sangat valid), validasi konstruk 100\% (sangat valid) dan validasi praktisi $88 \%$ (sangat valid), sehingga rata-rata hasil validasi memperoleh persentase sebesar $94 \%$ (sangat valid). Berdasarkan angket respon siswa diperoleh 93\% (sangat baik) Berdasarkan yang telah dipaparkan bahwa modul IPA berbasis pendekatan kontekstual yang telah dikembangkan berkualitas.
\end{abstract}

Kata Kunci: Modul IPA, Pendekatan Kontekstual, Hubungan Makhluk Hidup dan Lingkungannya

\section{ABSTRACT}

This study aimed to produce teaching materials in the form of IPA Modules of living creatures and the environment based on a quality contextual approach in terms of expert validation and testing to students. This development research uses the ADDIE model development procedure (analysis, design, development, implementation, evaluation). The subjects of this study are students of grade IV-B SD Negeri 033 Tarakan with a total of 24 people. Criteria for quality of IPA module material of living creature relationship and environment, viewed material validation result $98 \%$ (very valid), design validation $87.5 \%$ (very valid), validation of language $97 \%$ (very valid), $100 \%$ validation validation (very valid) and validation practitioner $88 \%$ (very valid), so the average validation result gets a percentage of $94 \%$ (very valid). Based on the questionnaire, the students' responses were 93\% (very good) Based on what has been explained that the IPA module based on the contextual approach that has been developed is qualified.

Keywords: IPA Module, Contextual Approach, Relationship of Living Beings and Environment

\section{PENDAHULUAN}

Tujuan Pendidikan yang tercantum dalam Undang-Undang No 20 tahun 2003 tentang Sistem Pendidikan Nasional menyebutkan bahwa pendidikan dalam proses pembelajaran yang aktif dan efektif mampu mengembangkan potensi diri siswa, sehingga memiliki sikap spiritual keagamaan yang baik, memiliki akhlak yang mulia, memiliki kecerdasan yang baik serta memiliki keterampilan yang dapat berguna bagi dirinya sendiri, masyarakat dan bangsa. Demi terciptanya tujuan pendidikan, maka diterapkan kebijakan wajib belajar dan program tersebut menjadi tanggung jawab Pemerintah dan Pemerintah Daerah. Wajib belajar adalah suatu program pendidikan minimal yang harus diikuti oleh warga Negara Indonesia tanpa 
terkecuali, pendidikan formal dimulai dari pendidikan dasar, pendidikan menengah dan pendidikan tinggi. Sekolah Dasar (SD) merupakan awal dari pendidikan dasar, sehingga usia anak 715 tahun setidaknya mendapatkan pendidikan dasar berbentuk (SD).

Pembelajaran di sekolah memiliki pedoman yang dinamakan kurikulum, kurikulum merupakan seperangkat rencana mengenai tujuan pembelajaran yang didalamnya terdapat isi, dan bahan dari suatu pelajaran, sehingga menjadi pedoman dalam kegiatan melaksanakan tujuan pembelajaran. Kurikulum yang digunakan setiap sekolah telah menjadi ketetapan pemerintah daerah, penggunaan kurikulum sesuai dengan pemerintah pusat menjadi pertimbangan bagi daerah-daerah lainnya. Penggunaan Kurikulum Tingkat Satuan Pendidikan (KTSP) yang merupakan penyempurnaan dari Kurikulum Berbasis Kompetensi (KBK) dikembangkan sesuai dengan relevansi yang berpusat pada potensi, perkembangan, kebutuhan serta kepentingan baik dari lingkungan maupun dari peserta didik itu sendiri, sehingga peserta didik mampu mengembangkan kompetensinya, agar menjadi manusia beriman dan bertakwa kepada Tuhan Yang Maha Esa.

Pembelajaran IPA merupakan mata pelajaran yang diperoleh sejak sekolah dasar, pembelajaran IPA tersebut melibatkan keaktifan siswa, baik aktivitas fisik maupun aktivitas mental, dan berhubungan langsung dengan kehidupan sehari-hari. Pembelajaran IPA pada dasarnya harus mengaitkan keadaan langsung dengan kenyataan yang sesungguhnya atau kondisi nyata, karena IPA mempelajari segala hal yang ada di bumi. Pembelajaran IPA akan menjadi lebih menarik dan bermutu, mulai dari gaya mengajar, penggunaan bahan ajar yang dapat melibatkan lingkungan sekitar, sehingga pembelajaran yang menarik tersebut dapat memberikan kesan yang bermakna dalam suatu pembelajaran, maka perlu adanya pembuatan bahan ajar yang menarik dan inovatif untuk memudahkan siswa dalam memahami materi pembelajaran, dan sebagai panduan guru dalam menyampaikan materi pembelajaran. Kenyataannya banyak guru kurang mengembangkan kemampuannya dalam menciptakan pembelajaran menjadi lebih bermakna, guru hanya lebih terpaku dan lebih menggunakan buku paket dan LKS, padahal kita ketahui bahwa bahan ajar bukan hanya buku paket dan LKS. Hal ini sejalan dengan pendapat Astika (2014), yang menyatakan bahwa peran guru dalam kurikulum KTSP tidak hanya sebagai pengajar namun sebagai fasilitator dalam proses pembelajaran yang dituntut untuk mempunyai kemampuan dalam mengelola dan mengembangkan bahan ajar. Hal itu juga merupakan bagian dari kompetensi pedagogik yang harus dikuasai guru, yaitu menggunakan media pembelajaran dan sumber belajar yang relevan dengan karakteristik peserta didik dan mata pelajaran yang diampu untuk mencapai tujuan pembelajaran secara utuh. Kompetensi yang harus dikuasai guru, yang mengacu pada Permendiknas No. 16 Tahun 2007 menyebutkan bahwa standar kualifikasi akademik dan standar kompetensi guru diuraikan bahwa standar kompetensi guru terdiri dari kompetensi pedagogik, kepribadian, sosial dan professional (Annisa, Hamid and Kartini, 2016)

Guru harus mengembangkan bahan ajar yang dapat digunakan dalam proses pembelajaran, hal ini cukup beralasan dikarenakan, pertama, bahan ajar yang sudah tersedia belum mencukupi kebutuhan sesuai tuntutan kurikulum, kedua, bahan ajar sudah tersedia belum sesuai dengan karakteristik sasaran, baik lingkungan fisik sosial, geografis, budaya dan karakteristik siswa. Ketiga, adanya tuntutan pemecahan masalah belajar (Depdiknas dalam Astika, 2014). Berdasarkan hasil observasi yang 
dilakukan di SDN 033 Tarakan, cara mengajar guru dengan menggunakan metode ceramah, selain itu bahan ajar yang digunakan siswa belum menyentuh kehidupan nyata di sekitar mereka, bahan ajar yang digunakan belum membuat siswa terlibat langsung dalam pembelajaran sehingga kurang memberi pengalaman langsung bagi siswa sehingga hasil Ujian Tengah semester siswa tidak ada yang mengalami ketuntasan. Guru mata pelajaran IPA/guru kelas belum pernah membuat bahan ajar yang dapat digunakan untuk proses pembelajaran. Kurangnya kemampuan guru dalam mengembangkan bahan ajar dikarenakan ketidakpahaman dalam merancang bahan ajar dan keterbatasan waktu. Materi Hubungan Makhluk Hidup dan Lingkungannya merupakan materi pembelajaran IPA sekolah dasar yang erat kaitannya dengan permasalahan dalam kehidupan seharihari, materi tersebut masih bersifat abstrak jika tidak menggunakan bahan ajar yang tepat dalam menyampaikan materi tersebut, namun kenyataannya dalam penyampaian materi tersebut masih bersifat monoton, dan menjadikan bahan ajar buku paket dan LKS sebagai sumber satu-satunya dalam proses pembelajaran. Maka diperlukan bahan ajar yang tepat dalam menyelesaikan permasalahan tersebut. Adanya bahan ajar yang tepat, maka materi yang bersifat rumit atau abstrak dapat dijelaskan dengan mudah. Hal ini melatarbelakangi pemilihan materi hubungan makhluk hidup dan lingkungannya.

Berdasarkan uraian yang telah dikemukakan, pendekatan pembelajaran yang tepat dalam mengatasi permasalahan yang sesuai dengan yang dikemukakan adalah pendekatan kontekstual. Pendekatan ini dipilih karena dengan menggunakan pendekatan ini, siswa bisa mendapatkan pengalaman langsung secara nyata, sehingga dapat membuat pembelajaran lebih bermakna. Pembelajaran kontekstual merupakan suatu strategi pembelajaran yang selain dapat menghubungkan dunia kehidupan nyata siswa dengan sekolah, juga diyakini akan menghasilkan suatu pemahaman yang mendalam terhadap materi-materi yang disajikan oleh guru (Crawford dalam Habibi, 2016). Abrori and Adhani (2017) juga menyatakan bahwa kemampuan siswa sebagai peserta didik dalam mengatasi dan berpikir kritis dalam pembelajaran yang berbasis potensi lokal akan berdampak pada peningkatan hasil belajar mereka. Hal ini senada dengan Nasiroh (2014), yang mengatakan bahwa penggunaan pendekatan kontekstual akan menciptakan pembelajaran yang menekankan pada keterkaitan antara materi pembelajaran dengan dunia kehidupan siswa secara nyata. Dengan demikian, pembelajaran yang menggunakan pendekatan kontekstual akan melibatkan siswa secara langsung dalam permasalahan kehidupan sehari-hari dan lingkungannya.

Berdasarkan uraian yang telah dikemukakan maka peneliti tertarik untuk mengembangkan bahan ajar materi hubungan makhluk hidup dan lingkungannya berbasis pendekatan kontekstual. Bahan ajar yang dikembangkan berupa modul pembelajaran. Depdiknas (2008) mengatakan bahwa modul adalah salah satu bentuk bahan ajar yang digunakan oleh siswa agar dapat belajar secara mandiri. Tergambar jelas bahwa modul digunakan untuk belajar mandiri dan diharapkan mampu meningkatkan motivasi peserta didik dalam pencapaian hasil belajar. Penyusunan modul harus disesuaikan dengan kompetensi dan standar kompetensi yang akan dikembangkan. Hal ini didukung oleh pernyataan Yanti, (2017) mengatakan bahwa modul sangat diperlukan sebagai inovasi baru untuk penunjang keberhasilan siswa dalam memahami isi materi pembelajaran. Sulisyanti (2017) mengatakan bahwa dengan menggunakan modul, peserta didik dapat mengukur tingkat 
penguasaannya terhadap materi yang dibahas pada setiap satuan modul. Jadi, dapat disimpulkan bahwa modul dapat digunakan sebagai panduan guru dalam menyampaikan pembelajaran secara satu kesatuan. Penyajian materi pada modul disesuaikan dengan pendekatan yang digunakan, yaitu pendekatan kontekstual yang dimana terdapat tujuh ciri khas dari pendekatan kontekstual tersebut.

Bahan ajar berupa modul pembelajaran IPA yang dikembangkan memiliki beberapa keunggulan yang akan membuat siswa menjadi belajar secara mandiri, lebih aktif, dan efisien dalam pembelajaran, serta dapat memvisualkan objek yang abstrak, kemudian dapat digunakan dalam pencapaian tujuan materi sehingga lebih mudah dipahami. Penyajian modul yang menarik menjadi daya tarik bagi pembacanya, sehingga dapat menambah pengetahuan dan menghilangkan kebosanan. Hal ini didukung oleh pernyataan Sudarno, Sunarno and Sarwanto (2015) yang mengatakan bahwa, modul yang baik tidak hanya menarik tetapi juga harus bisa merangsang rasa ingin tahu peserta didik terhadap ilmu yang dipelajari. Apabila peserta didik memiliki rasa ingin tahu yang tinggi terhadap materi pembelajaran, maka peserta didik akan lebih termotivasi untuk belajar.
Mengacu dari permasalahan yang telah diuraikan, maka peneliti akan mengembangkan bahan ajar berupa modul pembelajaran IPA berbasis pendekatan kontekstual sebagai alternatif dalam mengatasi permasalahan yang telah dipaparkan. Nasiroh (2014) mengatakan bahwa dengan perantara modul, setidaknya guru dapat mengaitkan pembelajaran, sehingga pembelajaran menjadi lebih bermakna, menyenangkan dan mudah dipahami. Berdasarkan uraian-uraian tersebut maka peneliti mengambil judul "Pengembangan Modul IPA Materi Hubungan Makhluk Hidup dan Lingkungan Berbasis Pendekatan Kontekstual".

\section{METODE PENELITIAN}

Model penelitian pengembangan ini menggunakan alur model ADDIE yang diadaptasi oleh Pribadi (2009), yang meliputi tahap pertama analysis (analisis), kedua design (perancangan), ketiga development (pengembangan), keempat implementation (implementasi) dan kelima evaluation (evaluasi). Pada penelitian ini hanya dilakukan sampai pada tahap implementasi. Tahap pelaksanaan penelitian dengan menggunakan model ADDIE dapat dilihat pada Tabel 1 berikut.

Tabel 1. Alur Penelitian dengan menggunakan model ADDIE

\begin{tabular}{cl}
\hline Analisis & $\begin{array}{l}\text { Mengidentifikasi permasalahan yang terjadi pada siswa serta mengidentifikasi } \\
\text { kebutuhan yang diperlukan dalam proses pembelajaran, terutama dalam hal } \\
\text { penggunaan bahan ajar dengan memberikan angket kepada siswa dan melakukan } \\
\text { observasi dan wawancara dengan guru. }\end{array}$ \\
\hline Desain & $\begin{array}{l}\text { Merancang draft bahan ajar, yaitu berupa modul berdasarkan analisis kerja dan } \\
\text { analisis keutuhan yang sudah dilakukan, yaitu modul pembelajaran IPA dengan } \\
\text { menggunakna pendekatan konteksual dan mengumpulkan data dan sumber } \\
\text { untukpmbuatan modul tersebut. }\end{array}$ \\
\hline Pengembangan & $\begin{array}{l}\text { Penilaian oleh validasi ahli yang meliputi Validasi ahli materi,Bahasa, desain, } \\
\text { konstruk dan praktisi }\end{array}$ \\
\hline Implementasi & $\begin{array}{l}\text { Penerapan uji coba kepada siswa. Uji coba terbatas terdiri dari 6 siswa, sedangkan } \\
\text { uji coba skala besar pada ssiwa kelas IVB yang berjumlah 24 orang. Uji coba } \\
\text { kepada siswa digunakan untuk mendeskripsikan respon siswa terhadap modul yang } \\
\text { digunakan dengan menggunkn pendekatan kontektual. }\end{array}$ \\
\hline
\end{tabular}




\section{HASIL PENELITIAN}

Validasi Produk Validasi produk dilakukan untuk mendeskripsikan kualitas modul yang ditinjau penilaian validasi ahli materi, ahli desain, ahli bahasa, ahli konstruk dan praktisi. Berikut hasil rekapitulasi persentase skor hasil penilaian dari ke lima validator, yang dapat di lihat pada tabel 2 .

Tabel 2. Rekapitulasi Persentase Skor Validasi Ahli

\begin{tabular}{clcl}
\hline No & Validator & $\begin{array}{c}\text { Persentase } \\
\text { Skor }(\%)\end{array}$ & Ket. \\
\hline 1 & Ahli Materi & $98 \%$ & Sangat Valid \\
3 & Ahli Bahasa & $97 \%$ & Sangat Valid \\
2 & Ahli Desain & $87.5 \%$ & Sangat Valid \\
4 & Ahli Konstruk & $100 \%$ & Sangat Valid \\
5 & Praktisi & $88 \%$ & Sangat Valid \\
\hline Rata-rata & $\mathbf{9 4 \%}$ & Sangat Valid \\
\hline
\end{tabular}

Hasil dari analisis respon siswa terdiri dari dua uji coba. Uji coba pertama dilakukan dengan jumlah 6 orang siswa, sedangkan uji coba kedua dilakukan dengan jumlah 24 orang siswa atau pada subjek uji coba penelitian ini. Hasil dari uji coba terbatas dapat di lihat pada tabel 3 dan hasil analisis respon siswa uji coba lapangan dapat di lihat pada tabel 4.

Tabel 3. Hasil Angket Respon Siswa Uji Coba Terbatas

\begin{tabular}{clcl}
\hline No. & \multicolumn{1}{c}{ Aspek } & Persentase & Keterangan \\
\hline 1. & Kemudahan & $100 \%$ & Sangat Baik \\
\hline 2. & Kemenarikan & $95 \%$ & Sangat Baik \\
\hline 3. & Keterpahaman & $98 \%$ & Sangat Baik \\
\hline
\end{tabular}

Berdasarkan hasil repon yang diberikan siswa pada saat uji coba terbatas dengan jumlah 6 orang siswa di kelas V-D SD Negeri 033 Tarakan, maka peneliti melakukan perbaikan-perbaikan berdasarkan catatan saran dan komentar yang diberikan siswa.

Hasil respon yang diberikan siswa pada saat uji coba lapangan menunjukkan aspek kemudahan, kemenarikan, dan keterpahaman siswa terhadap modul yang dikembangkan sangat baik. Hasil analisis yang dilakukan sebagaimana tabel 4 .
Tabel 4. Hasil Angket Respon Siswa Uji Coba Lapangan

\begin{tabular}{llcl}
\hline No & \multicolumn{1}{c}{ Aspek } & Persentase & Keterangan \\
\hline 1. & Kemudahan & $91.6 \%$ & Sangat Baik \\
\hline 2. & Kemenarikan & $84.33 \%$ & Sangat Baik \\
\hline 3. & Keterpahaman & $88.07 \%$ & Sangat Baik \\
\hline \multicolumn{2}{r}{ Rata-rata } & & Sangat Baik \\
\hline
\end{tabular}

\section{PEMBAHASAN \\ Validasi Ahli}

Validasi ahli terdiri dari ahli materi, ahli desain, ahli bahasa, ahli konstruk dan praktisi. Uji validasi materi dilakukan oleh satu orang dosen Jurusan Pendidikan Guru Sekolah Dasar Universitas Borneo Tarakan dengan mendapatkan persentase skor $98 \%$ dengan kategori sangat valid, indikator penilaian materi meliputi : kelengkapan materi yang disajikan terkandung dalam $\mathrm{KD}$, yang mendapat skor $100 \%$, hal ini disebabkan oleh materi yang disajikan di dalam modul sudah sesuai dengan kompetensi dasar (KD) dalam kurikulum 2006. Hal ini senada dengan pendapat Prastowo (2015), kompetensi dasar yang tercantum dalam modul diambil dari pedoman khusus kurikulum, selanjutnya indikator keluasan materi yang disajikan mendukung pencapaian kompetensi dasar, yang mendapatkan skor $100 \%$, hal ini disebabkan oleh materi yang disajikan di dalam modul dapat mendukung pencapaian kompetensi dasar, Prastowo (2015), mengatakan bahwa materi atau isi modul akan sangat bergantung pada kompetensi dasar yang akan dicapai, selanjutnya indikator kedalaman materi yang disajikan sesuai dengan tingkat pendidikan SD/MI, yang mendapat skor $100 \%$ hal ini disebabkan materi yang disajikan di dalam modul sesuai dengan tingkat pendidikan SD/MI, sesuai dengan pendapat Rahdiyanta (2017) mengatakan bahwa materi berisi uraian pengetahuan/ konsep/prinsip tentang kompetensi yang sedang dipelajari.

Indikator keakuratan konsep dan definisi mendapatkan skor $100 \%$ hal ini disebabkan, terdapatnya keakuratan konsep di dalam modul. Materi/subtansi 
yang ada dalam modul berupa konsep/ prinsip-prinsip, fakta penting yang terkait langsung dan mendukung untuk pencapaian kompetensi dan harus dikuasai oleh peserta didik (Rahdiyanta, 2017). Indikator keakuratan fakta dan data yang disajikan sesuai dengan kenyataan dan efisien untuk meningkatkan pemahaman peserta didik, indikator tersebut mendapatkan skor $100 \%$ hal ini disebabkan di dalam modul data disajikan sesuai dengan kondisi fisik atau fakta yang ada disekitar lingkungan peserta didik, seperti gambar yang disajikan dalam modul merupakan gambar-gambar yang sering mereka temui dalam kehidupan sehari-hari, sehingga modul pembelajaran IPA yang dikembangkan dapat meningkatkan pemahaman peserta didik, hal ini sesuai dengan Rahdiyanta (2017) mengatakan bahwa penulisan modul bertujuan untuk meningkatkan motivasi dan gairah belajar siswa.

Indikator keakuratan contoh dan kasus sesuai kenyataan dan efisien untuk pemahaman peserta didik, yang mendapatkan skor $100 \%$, hal ini dikarenakan modul IPA yang dikembangkan terdapat contoh-contoh atau kasus yang sesuai dengan kenyataan sebagaimana pendapat Rahdiyanta (2017) bahwa modul harus tersedia contoh dan ilustrasi yang mendukung kejelasan pemaparan materi pembelajaran. Indikator selanjutnya keakuratan gambar yang disajikan sesuai dengan kenyataan dan efisien untuk meningkatkan pemahaman peserta didik, di dalam modul terdapat gambar-gambar yang disajikan sesuai dengan kenyataan dan lingkungan sekitar peserta didik, seperti contoh gambar yang terdapat di dalam modul misalkan contoh gambar kebun jagung, ekosistem laut yang didapat dari lingkungan sekitar peserta didik sehingga menimbulkan daya tarik untuk mempelajarinya, karena sesuai dengan pendapat Prastowo (2015), mengatakan bahwa gambar-gambar yang disajikan di dalam modul tidak hanya dapat mendukung penjelasan materi, tetapi untuk dapat menambah daya tarik dan mengurangi rasa kebosanan. Indikator gambar dan ilustrasi yang disajikan terdapat dalam kehidupan sehari-hari, dan dilengkapi penjelasan, pada indikator tersebut mendapatkan skor $100 \%$ hal ini dikarenakan gambar yang disajikan dalam modul sesuai dengan kehidupan sehari-hari kemudian setiap gambar yang disajikan terdapat penjelasan mengenai gambar tersebut, hal ini sesuai dengan pendapat Prastowo (2015), mengatakan bahwa terdapat gambar di dalam modul dan penjelasan materinya.

Indikator menciptakan kemampuan bertanya yang disajikan dalam uraian, yang mendapatkan skor $100 \%$ hal ini sesuai dengan yang terdapat di modul bahwa uraian materi yang disajikan dapat menciptakan kemampuan peserta didik untuk bertanya. Indikator selanjutnya, terdapat latihan atau contoh-contoh kasus, yang mendapatkan skor $100 \%$ hal ini sesuai dengan karakteristik modul bahwa soal latihan tugas atau sejenisnya yang memungkinkan untuk mengukur pemahaman siswa (Rahdiyanta, 2017).

Uji validasi desain dilakukan oleh dosen PPKIA Tarakanita dengan memperoleh skor sebesar $87.5 \%$ dengan kategori sangat valid. Penjelasan penilaian tiap-tiap indikator sebagai berikut: indikator ukuran modul, ukuran yang digunakan modul IPA materi hubungan makhluk hidup dan lingkungannya, sesuai dengan standar iso yaitu B5 (176 x $250 \mathrm{~mm}$ ) sesuai dengan pedoman penyusunan modul dalam (BSNP, 2016) selanjutnya indikator ilustrasi modul yang mendapatkan skor $100 \%$, hal ini dikarenakan ilustrasi yang terdapat dalam modul mampu mengungkapkan materi sesuai dengan kenyataan dan disajikan dalam bentuk kreatif dan menarik, dan peneliti mengambil gambar langung sesuai dengan materi yang disajikan hal ini sesuai dengan panduan (BSNP, 2016). 
Uji validasi bahasa dilakukan oleh dosen Jurusan Pendidikan Bahasa dan Sastra Indonesia Universitas Borneo Tarakan yang mendapatkan skor $97 \%$ dengan kategori sangat valid. Berikut penjelasan dari tiap-tiap indikator : Lugas, pada indikator tersebut mendapatkan skor $100 \%$ hal ini dikarenakan penyajian struktur kalimat yang tepat, kefeektifan kalimat dan kebakuan istilah yang terdapat dalam modul, sesuai dengan panduan (BSNP, 2016). Indikator selanjutnya, komunikatif yang mendapatkan skor $100 \%$ hal ini dikarenakan modul dapat membuat siswa menjadi lebih paham terhadap pesan atau informasi yang disajikan. Modul harus menggunakan bahasa yang sederhana dan komunikatif (Rahdiyanta, 2017). Indikaor dialogis dan interaktif pada indikator tersebut mendapatkan skor $100 \%$ hal ini dikarenakan penyajian bahasa yang interaktif di modul dapat mendorong siswa untuk bertanya, selanjutnya indikator kesesuaian dengan perkembangan peserta didik, bahasa yang digunakan dalam modul tersebut sesuai dengan usia dan jenjang pendidikan siswa.

Uji validasi konstruk dilakukan oleh dosen Jurusan Pendidikan Guru Sekolah Dasar yang mendapatkan skor $100 \%$ dengan kategori sangat valid. Hal ini disebabkan oleh seluruh indikator yang mendapatkan masing-masing skor $100 \%$. Hasil penilaian dari validasi konstruk dijelaskan sebagai berikut: menuliskan standar kompetensi, menuliskan kompetensi dasar, menuliskan indikator, pada indikator tersebut modul yang dikembangkan telah sesuai dengan standar kompetensi yang sesuai dengan kurikulum 2006 serta menuliskan SK, $\mathrm{KD}$ dan Indikator tersebut dalam pendahuluan (petunjuk umum modul) sesuai dengan struktur modul Surahman (Prastowo, 2015).

Indikator adanya keterkaitan materi yang diajarkan dengan situasi dunia nyata siswa, pada indikator tersebut mendapat- kan skor $100 \%$ hal ini dikarenakan materi yang disajikan dalam modul sesuai dengan kondisi dan kenyataan yang terdapat di lingkungan sekolah. Indikator pembelajaran mendorong siswa membuat hubungan antara pengetahuan yang dimiliki siswa dengan penerapannya dalam kehidupan sehari-hari, indikator tersebut mendapatkan skor $100 \%$ hal tersebut dikarenakan di dalam modul terdapat pengetahuan yang dapat siswa terapkan dalam kehidupan sehari-hari, karena pendekatan yang digunakan dalam modul berbasis pendekatan kontekstual. Indikator materi dalam modul bersifat mengkontruksi pengetahuan dan bukan menerima pengetahuan, indikator tersebut mendapatkan skor $100 \%$ hal ini disebabkan siswa dapat belajar untuk menemukan pengetahuan baru melalui kegiatan berbasis pendekatan kontekstual. Indikator materi merangsang siswa untuk menemukan pengetahuan sendiri, pada indikator tersebut mendapatkan skor $100 \%$ hal ini disebabkan karena pembelajaran yang terdapat dalam modul tidak hanya didapatkan dari membaca tetapi membuat siswa untuk menemukan pengetahuannya sendiri berdasarkan fakta lingkungan sekitar, seperti menemukan contohcontoh hubungan simbiosis dan ekosistem di lingkungan sekitar sekolah. Indikator selanjutnya terdapat pertanyaan-pertanyaan yang mendorong membimbing, dan mengukur kemampuan berpikir siswa, indikator tersebut mendapatkan skor $100 \%$ karena di dalam modul terdapat beberapa pertanyaanpertanyaan yang dapat membimbing siswa untuk belajar mandiri dan mengukur kemampuan siswa hal ini sesuai dengan tujuan modul yang dikemukakan Rahdiyanta (2017) yang mengatakan bahwa memungkinkan siswa dapat mengukur dan menilai hasil kemampuan hasil berpikir siswa. Terdapat tugas kelompok, dan materi merangsang siswa untuk berdiskusi (sharing) dengan teman-temannya, 
indikator tersebut mendapatkan skor $100 \%$ hal ini dikarenakan terdapat tugas kelompok siswa yang dapat membelajarkan siswa secara berkelompok karena di dalam pendekatan kontekstual terdapat pembelajaran kelompok. Terdapat gambar-gambar sebagai penguat materi, indikator tersebut mendapatkan skor $100 \%$ hal ini dikarenakan di dalam modul terdapat gambar-gambar yang digunakan sebagai penjelas materi. Terdapat rangkuman atas materi yang telah dipelajari, pada indikator tersebut mendapatkan skor $100 \%$ hal ini dikarenakan sesuai dengan karakteristik modul yang terdapat rangkuman materi pembelajaran (Rahdiyanta, 2017).

Uji validasi praktisi dilakukan oleh salah satu guru SD Negeri 033 Tarakan yang mendapatkan skor $88 \%$ dengan kategori sangat valid yang ditunjukkan pada indikator, mencakup materi yang ada dalam KTSP, kelengkapan modul pembelajaran yang sesuai dengan Widodo (Asyhar, 2011) pembuatan modul harus disesuaikan dengan kriteriakriteria yang telah ditetapkan dan harus dilakukan secara sistematis, sesuai dengan kaidah-kaidah yang baik. Kaidah struktur penulisan modul adalah sebagai berikut: bagian pembuka yang meliputi judul, daftar isi, peta informasi, tujuan kompetensi, bagian inti yang meliputi pendahuluan, hubungan dengan materi yang lain, uraian materi, dan kegiatan belajar, dan bagian penutup meliputi, glossary, dan indeks.

Berdasarkan penilaian ahli materi sebesar $98 \%$ yang dikategorikan sangat valid, penilaian ahli desain sebesar $87.5 \%$ yang dikategorikan sangat valid, penilaian ahli bahasa sebesar $97 \%$ yang dikategorikan sangat valid, penilaian ahli konstruk sebesar $100 \%$ yang dikategorikan sangat valid, penilaian praktisi sebesar $88 \%$. Penilaian secara umum mengenai modul IPA materi hubungan makluk hidup dan lingkungannya berbasis pendekatan kontekstual, dapat dikatakan sangat valid oleh validator.

Kevalidan modul IPA materi hubungan makluk hidup dan lingkungannya berbasis pendekatan kontekstual, yang dapat disimpulkan dengan melihat persentase skor dari penilaian ahli materi, ahli desain, ahli bahasa, ahli konstruk, dan praktisi. Persentase skor dari kelima validator tersebut dapat di lihat pada tabel 1 dengan persentase skor $94 \%$ dengan kategori sangat valid. Hal ini sejalan dengan hasil penelitian (Astika, 2014) yang menyatakan bahwa modul yang berkualitas dilihat dari aspek kevalidan apabila menunjukkan kategori sangat valid atau valid dari penilaian para validator ahli.

\section{Respon Siswa}

Hasil analisis angket respon siswa dapat di lihat pada tabel 5 diperoleh skor persentase $97.76 \%$, sehingga dapat dikategorikan sangat baik. Aspek respon terdiri dari aspek kemudahan, aspek kemenarikan dan aspek keterpahaman. Aspek kemudahan terdiri: a) modul menggunakan bahasa yang mudah dimengerti (95.8\%); b) petunjuk yng terdapat dalam modul mudah dimengerti $(83.3 \%)$ dan c) pemilihan huruf dan ukuran sangat memudahkan saya dalam membaca $(95.8 \%)$. Penggunaan bahasa pada modul mendapatkan skor dengan kategori sangat baik (95.8\%), hal ini dikarenakan bahasa yang disajikan dalam modul, disesuaikan dengan sasaran penggunanya, karena modul ditunjukkan pada siswa SD maka gaya penulisan tidak terlalu formal. Hal ini sesuai dengan yang diungkapkan Prastowo (2015), yang mengatakan bahwa, gaya penulisan bahan ajar yang dikembangkan harus disesuaikan dengan materi dan kemampuan peserta didik.

Aspek respon siswa selanjutnya yaitu aspek kemenarikan, yaitu : a) Saya menyukai warna yang ada di modul $(84.3 \%)$; c) Penyajian modul sangat menarik $(81.2 \%)$; c) Saya menjadi 
bersemangat mengikuti pembelajaran yang ada di modul (86.4\%); d) Saya termotivasi belajar IPA setelah menggunakan modul ini (85.4\%). Pemilihan warna pada modul sehingga modul menarik mendapakan skor dengan kategori sangat baik, hal ini dikarenakan pemilihan jenis huruf dan font, menjadikan modul lebih menarik. Hal ini sesuai dengan pernyataan (Prastowo, 2015), yang mengatakan bahwa peneliti harus berani mencoba membuat modul inovatif dan menarik, misalkan dengan penggunaan variasi format tampilan fisik, dan menggunakan jenis dan ukuran font yang berbeda.

Aspek keterpahaman, terdiri dari : a) Gambar di modul berfungsi menyampaikan maksud pada materi $(88.5 \%)$; b) Penyampaian informasi sangat jelas $(95.8 \%)$; c) Modul IPA ini mencakup kehidupan nyata atau seharihari (89.5\%); d) Saya memperoleh pengetahuan dari modul ini $(86.4 \%)$; e) Saya dapat menerapkan isi modul yang telah saya pelajari dalam kehidupan sehari-hari $(89.5 \%)$; f) Saya memahami materi modul berbasis pendekatan kontekstual ini $(82.2 \%)$. Secara keseluruhan, aspek keterpahaman memiliki skor $88.07 \%$ dan berada pada kategor sangat baik. Hal ini menunjukkan bahwa modul dapat mudah dipahami siswa. Hasil penilaian juga dilihat dari catatan dan komentar siswa, catatan dan komentar siswa tersebut digunakan sebagai bahan revisi dan penyempurnaan produk. Adapun komentar siswa sebagai berikut: saya menyukai modul IPA ini cukup bagus, saya kira cukup dimengerti pelajarannya (AGF), modul ini sudah bagus sekali tetapi masih ada yang tidak saya mengerti, tapi modul sudah bagus sekali saya bisa belajar (RGN). Hal ini sejalan dengan penelitian yang telah dilakukan oleh Asysyifa, Sopyan and Masturi (2017) yang mengatakan bahwa hasil respon siswa apabila menunjukkan efektif atau baik maka produk yang telah dikembangkan tersebut diterima oleh siswa.

\section{KESIMPULAN}

1. Kualitas modul IPA materi hubungan makluk hidup dan lingkungannya berbasis pendekatan kontekstual yang dikembangkan, ditinjau dari aspek kevalidan, memperoleh skor 94\% (sangat valid). Hal ini dapat dijabarkan sebagai berikut: validasi ahli materi $98 \%$ (sangat valid), validasi ahli desain $87.5 \%$ (valid), validasi bahasa $97 \%$ (sangat valid) dan validasi ahli konstruk $100 \%$ (sangat valid) dan validasi praktisi $88 \%$ (sangat valid).

2. Kualitas modul IPA materi hubungan makhluk hidup dan lingkungannya berbasis pendekatan kontekstual yang dikembangkan, ditinjau dari angket respon siswa diperoleh $93 \%$ (sangat baik).

\section{SARAN}

Berdasarkan kesimpulan yang diperoleh, saran yang diberikan adalah sebagai berikut:

1. Modul IPA materi hubungan makluk hidup dan lingkungannya berbasis pendekatan kontekstual, yang telah dikembangkan sudah cukup memadai dalam proses pembelajaran, namun alangkah lebih baik guru dapat mengembangkan modul IPA ini menjadi materi lebih luas.

2. Jika dibutuhkan, perlu pengembangan bahan ajar modul IPA materi hubungan makluk hidup dan lingkungannya berbasis pendekatan kontekstual, sesuai dengan kebutuhan siswa serta kondisi sekolah, sehingga terciptanya pembelajaran yang aktif dan menyenangkan.

3. Modul diharapkan dapat digunakan dengan maksimal untuk pembelajaran IPA materi hubungan makhluk hidup dan lingkungannya pada kelas IV Sekolah Dasar. 
4. Peneliti selanjutnya dapat mengembangkan modul IPA menggunakan pendekatan kontekstual, kemudian dapat mengembangkan modul pada materi lainnya.

\section{DAFTAR PUSTAKA}

Abrori, M. . and Adhani, A. (2017) 'Pengembangan Buku Ajar Berbasis Potensi Lokal Keragaman Tumbuhan Paku di Daerah Tarakan', in Prosiding Seminar Nasional Saling Didik 4. Tarakan, pp. 328-332.

Annisa, M., Hamid, H. and Kartini (2016) 'Pengembangan

Profesionalisme Guru melalui Pelatihan Penyusunan Karya Tulis Ilmiah di Wilayah Pedalaman', Jurnal Widya Laksana, 5(2), pp. 81-84.

Astika, F. F. (2014) Pengembangan Modul pada Materi Matriks dengan Pendekatan PMRI untuk Siswa Kelas $X$ SMK. UNIVERSITAS NEGERI YOGYAKART.

$\begin{array}{cr}\text { Asyhar, R. (2011) } & \text { Kreatif } \\ \text { Mengembangkan } & \text { Media } \\ \text { Pembelajaran. Jakarta: } & \text { Gaung } \\ \text { Persada (GP) Press Indonesia. }\end{array}$

Asysyifa, D. S., Sopyan, A. and Masturi (2017) 'Pengembangan Bahan Ajar IPA Berbasis Komplementasi AyatAyat Sains Quran pada Pokok Bahasan Sistem Tata Surya', Unnes Physics Education Journal, 6(1), pp. 44-54.

BSNP, B. S. N. P. (2016) 'Instrumen Penilaian Buku Teks'. Jakarta: Badan Standar Nasional Pendidikan. Available at: http://bsnpindonesia.org/instrumen-penilaianbtp-sd-kelas-iv/kegrafikaan/.

Depdiknas (2008) 'Penulisan Modul'. Jakarta: Direktorat Tenaga Kependidikan Ditjen PMPTK, Depdiknas.
Habibi (2016) 'Pengembangan Strategi Pembelajaran IPA Kontekstual Berbasis Ekosistem Mangrove', LENSA (Lentera Sains): Jurnal Pendidikan IPA, 6(2), pp. 69-75.

Nasiroh, D. (2014) Pengembangan Modul dengan Pendekatan Kontekstual pada Materi barisan dan Deret untuk Siswa SMP Terbuka Kelas IX. Universitas Negeri Yogyakarta.

Prastowo, A. (2015) Panduan Kreatif Membuat Bahan Ajar Inovatif. Jogjakarta: DIVA Press.

Pribadi, B. A. (2009) Model Desain Sistem Pembelajaran. Jakarta: PT. Dian Rakyat.

Rahdiyanta, D. (2017) 'TEKNIK PENYUSUNAN MODUL'. Available at: http://mgmppjoksmpkotabekasi.co $\mathrm{m} / \mathrm{wp}$ content/uploads/2017/04/TEKNIKPEMBUATAN-MODUL.pdf.

Sudarno, Sunarno, W. and Sarwanto (2015) 'Pengembangan Modul IPA Terpadu Berbasis Kontekstual dengan Tema Pembuatan Tahu Kelas VII SMP Negeri 2 Jatiyoso', Jurnal Inkuiri, 4(3), pp. 104-111.

Sulisyanti (2017) Pengembangan Modul IPA Berorientasi Inkuiri Pada Materi Saling Ketergantunan Antar Makhluk Hidup Untuk Siswa Kelas IV SDN 043 Tarakan. Universitas Borneo Tarakan.

Yanti, S. R. (2017) Pengembangan Modul Biologi SMA Kelas X Pada Materi Invertebrata Berdasarkan Analisis Struktur Komunitas Gastropoda Di Kawasan Pulau Tundung Kabupaten Bulungan. Universitas Borneo Tarakan. 